\title{
Effects of ACE inhibitors on coronary atherosclerosis and restenosis
}

Department of Cardiology, London Chest Hospital, London A D Timmis

Department of Internal Medicine, University of Michigan, Ann Arbor, Michigan, USA B Pitt

Correspondence to: Dr A D Timmis, Department of Cardiology, London Chest Hospital, London E2 9JX.
The renin-angiotensin system was originally regarded as an endocrine system modulating vascular tone and salt and water balance by producing angiotensin II in the circulation and the lungs. More recently, independent tissue bound renin-angiotensin systems have been identified that produce angiotensin II locally in various tissues, including the heart and blood vessels. ${ }^{1-3}$ Local production of angiotensin II within the blood vessel wall, in addition to stimulating vasoconstriction, may promote smooth muscle growth and proliferation and contribute to the vascular hypertrophy that accompanies chronic hypertension. ${ }^{4}$ Increasing evidence suggests that angiotensin II may also be active in the pathogenesis of other vascular disorders, particularly atheromatous disease. Because the endocrine and tissue production of angiotensin II is amenable to inhibition by angiotensin converting enzyme (ACE) inhibitors, the potential exists to modify the progression of vascular disease pharmacologically. ${ }^{5-7}$ In this article we will review the evidence that implicates the renin-angiotensin system in the pathogenesis of atheromatous disease and will speculate on the therapeutic role of ACE inhibitors for this condition.

\section{Animal studies}

ENDOTHELIAL DYSFUNCTION

The link between atherosclerosis and endothelial dysfunction is well established. Thus, Harrison et al showed that in the iliac arteries of normal monkeys acetylcholine stimulates release of endothelium derived relaxation factor and acts as a vasodilator. ${ }^{8}$ In monkeys fed a high cholesterol, atherogenic diet, on the other hand, considerable intimal thickening occurs and endothelial function becomes impaired as reflected by noticeable reductions in the vasodilator response to acetylcholine. Importantly, however, the endothelial dysfunction is reversible and the vasodilator response to acetylcholine normalises after regression of intimal thickening in monkeys switched to a non-atherogenic diet.

ACE inhibitors may also improve endothelial function in atherosclerotic arteries. Becker et al found that ramipril given to rabbits fed an atherosclerotic diet preserved the vasodilator response to acetylcholine when compared with atherosclerotic control rabbits not given the ACE inhibitor. ${ }^{9}$ These investigators also showed a dose-dependent increase in cyclic guanine monophosphate concentrations in the aortic segments of the rabbits treated with ramipril compared with the controls. Cyclic guanine monophosphate concentration in vascular smooth muscle is a marker of release of endothelium derived relaxation factor by the endothelium; the data therefore confirm the value of ACE inhibition for preserving endothelial function in atherosclerotic arteries.

INTIMAL PROLIFERATION AND HYPERTROPHY AFTER ARTERIAL INJURY

Angiotensin II is a potent stimulus for smooth muscle cell growth and proliferation and its part in the atherosclerotic process is a subject of considerable interest. ${ }^{10}$ Powell et al subjected normotensive rats to balloon injury to the left internal carotid artery by means of a catheter. ${ }^{11}$ This produces traumatic endothelial denudation of the vessel wall and an injury response which includes migration and proliferation of smooth muscle cells in the arterial intima and synthesis of extracellular protein. These investigators found that treatment with ACE inhibitors produced considerable attenuation of the injury response. Thus, rats treated continuously with cilazapril or captopril had significantly less neointimal formation during the first 14 days after balloon injury compared with untreated control animals, presumably because of suppression of local angiotensin II activity by the ACE inhibitor and removal of the stimulus for smooth muscle migration and proliferation.

If the protective effects of ACE inhibitors against vascular smooth muscle responses to balloon injury are mediated locally by inhibition of the tissue renin-angiotensin system, then treatment with these drugs would be expected to lead to reductions in the density of ACE within the vessel wall. This hypothesis was tested by Johnston et al, who subjected spontaneously hypertensive rats to balloon injury resulting in denudation of the aortic endothelium. ${ }^{12}$ The density of ACE in the injured arterial segment was measured at necropsy by in vitro autoradiography. The autoradiographs showed an increase in ACE density (and neointimal formation) within the arterial segment eight days after balloon injury, but this was not seen in animals treated with quinapril, an ACE inhibitor that binds particularly strongly to vascular ACE. ${ }^{6}$ These findings suggest that local activation of the renin-angiotensin system is part of the neointimal response to vascular injury, and they raise the possibility that $A C E$ inhibitors such as quinapril may be useful for reducing the neointimal response. 


\section{Clinical trials}

Clinical trials investigating the influence of $\mathrm{ACE}$ inhibitors on the progression of coronary artery disease have not yet been reported. In progress, however, is the quinapril ischaemic event trial (QUIET), a prospective double blind, placebo controlled study designed to assess the ability of quinapril to reduce the rate of ischaemic events and to slow the progression of angiographic coronary artery disease in a normotensive, normolipidaemic population without left ventricular dysfunction. ${ }^{13}$ Quinapril was selected for this trial because it binds strongly to the tissue ACE within the vascular wall and may, therefore, be well suited to modify endothelial and neointimal changes that are driven by angiotensin II and form part of the atherosclerotic process. ${ }^{6}$ The results of QUIET will not be available until after the three year treatment phase has finished (projected for 1995). Meanwhile, clinical evidence that ACE inhibition may influence progression of coronary artery disease remains hypothetical and is based on analysis of the results of three major randomised trials (figure).

MULTICENTRE EUROPEAN RESEARCH TRIAL WITH CILAZAPRIL AFTER ANGIOPLASTY TO PREVENT TRANSLUMINAL CORONARY OBSTRUCTION AND RESTENOSIS (MERCATOR) The antiproliferative effects of cilazapril in the rat model of intimal balloon injury suggested a potential role for the drug for prevention of restenosis after coronary angioplasty. The MERCATOR investigators tested this hypothesis in 735 patients after successful angioplasty. They found that cilazapril did not prevent coronary restenosis at six months, patients randomly allocated to the ACE inhibitor showing reductions of minimal lumen diameter between angiograms after angioplasty and those at follow up of $-0 \cdot 27$ $(0.51) \mathrm{mm}$ compared with $-0.29(0.49) \mathrm{mm}$ in the control group. ${ }^{14}$ The failure of cilazapril to prevent restenosis was disappointing, particularly in view of the encouraging results

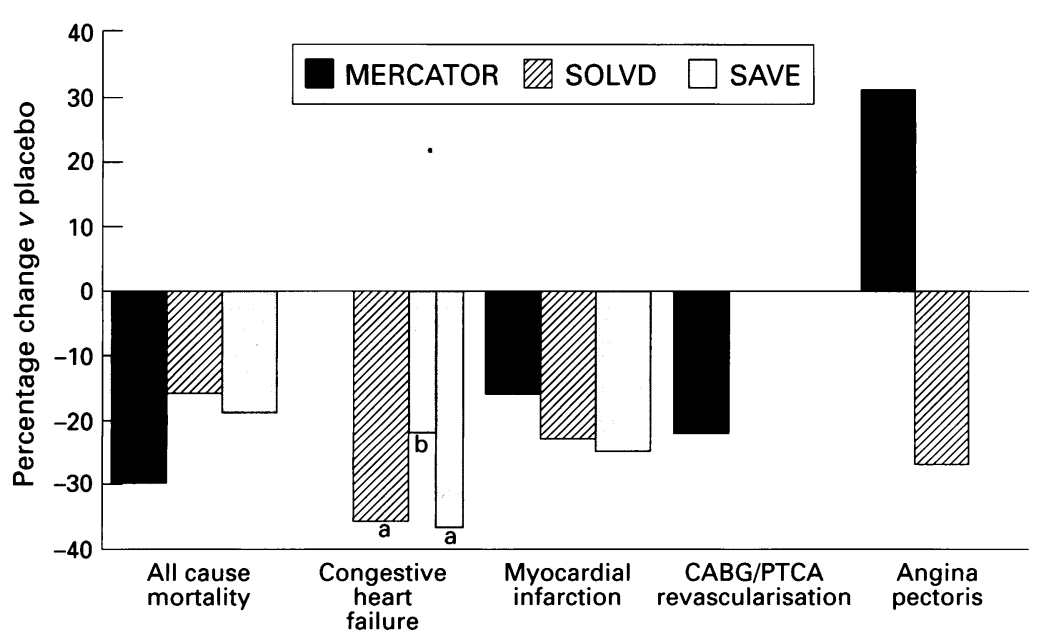

Percentage reduction in ischaemic events compared with placebo in MERCATOR, ${ }^{14}$ SOLVD, ${ }^{19}{ }^{20}$ and $S A V E^{24}$ trials. a, Admission to hospital for congestive heart failure; $b$, development of congestive heart failure; $C A B G$, coronary artery bypass grafting; PTCA, percutaneous transluminal coronary angioplasty. Reproduced with permission of Texter et al. ${ }^{13}$ in animals. However, the low dose of cilazapril ( $5 \mathrm{mg}$ twice daily) chosen for this study may have been insufficient. Thus, although $5 \mathrm{mg}$ cilazapril in humans reduces plasma ACE activity to almost undetectable amounts for up to eight hours during short term treatment, ${ }^{15}$ inhibition of neointima formation is dosedependent; in addition, the data of Powell et al in rats suggest that a higher dose may be necessary to influence the process of restenosis. ${ }^{16}$

Notwithstanding the low dose of cilazapril used in MERCATOR, it should not be inferred that because ACE inhibition has no effect on restenosis it will have no effect on the progression of coronary disease. We emphasise that MERCATOR was a restenosis trial and quite apart from the fact that restenosis is not a clinical surrogate of atherosclerotic disease, the six months of follow up was scarcely long enough to detect differences in the progression of disease between the two groups. Nevertheless, in MERCATOR the active treatment group showed a trend towards fewer clinical cardiac end points at 12 months, such as death, myocardial infarction, and coronary revascularisation (figure) ${ }^{17}$ It is possible to speculate, therefore, that had the dose of ACE inhibitor been higher and the treatment period longer, a more substantial effect on these cardiac end points might have been seen.

STUDIES OF LEFT VENTRICULAR DYSFUNCTION (SOLVD)

After publication of the results of the cooperative north Scandinavian enalapril survival study (CONSENSUS) showing that treatment with enalapril could improve survival in patients with advanced heart failure, ${ }^{18}$ interest turned to the potential benefits of ACE inhibition in patients with less severe disease. The SOLVD studies were designed to assess this potential by randomly allocating 2569 patients with predominantly class II or III heart failure according to the New York Heart Association's classification ("treatment trial") and 4228 patients with predominantly class I heart failure ("prevention trial") to treatment with enalapril or placebo. ${ }^{19} 20$ Follow up in both trials was for four years. The treatment trial confirmed that enalapril significantly reduced mortality in patients with symptomatic (class II to III) heart failure. Improved outcome using a combined end point (death and admission to hospital for heart failure) was also observed for the asymptomatic patients recruited in the prevention trial.

The SOLVD trials were not designed to evaluate the effects of ACE inhibition on the progression of coronary artery disease; recurrent myocardial infarction was recorded as part of the safety data for this trial as ACE inhibitors might cause hypotension and increase the rate of vascular occlusion. Surprisingly, enalapril reduced not only the frequency of myocardial infarction but also admission for unstable angina, even though about $30 \%$ of the patients did not have (or were not known to have) ischaemic heart disease (figure). Again, therefore, the SOLVD 
trials have led to speculation that $\mathrm{ACE}$ inhibition may protect against cardiovascular events by favourably influencing the progression of coronary artery disease in susceptible people.

\section{SURVIVAL AND VENTRICULAR ENLARGEMENT (SAVE) TRIAL}

Laboratory and clinical studies of acute myocardial infarction have shown that ACE inhibition can attenuate left ventricular dilatation and remodelling. ${ }^{21-23}$ The SAVE trial tested the hypothesis that this might reduce morbidity and mortality during long term follow up. ${ }^{24}$ Recurrent myocardial infarction was identified prospectively as a secondary outcome, although the way it was defined changed during the course of the study. A total of 2231 patients with left ventricular dysfunction (ejection fraction $\leqslant 40 \%$ ), most of whom were not receiving a diuretic, were randomly allocated to treatment with captopril or placebo three to 16 days after acute myocardial infarction. Significant reductions in cardiovascular end points were observed in the active treatment group, including death and progressive heart failure. Of particular interest, however, was the $25 \%$ reduction in the risk of recurrent infarction in the active treatment group, a benefit not readily explained by the effects of ACE inhibition on left ventricular remodelling (figure).

Like MERCATOR and SOLVD, therefore, the SAVE trial provides evidence to support the hypothesis that progression of coronary artery disease might be amenable to modification by ACE inhibition. We emphasise, however, that these trials were conducted only in patients with severe ventricular dysfunction. These patients may have an activated circulating or tissue renin-angiotensin system, or both. Moreover, myocardial infarction was not the primary outcome measure and definitions varied during the course of the trial. Until the results of QUIET become available, the exciting possibility that treatment of this type might reduce ischaemic events by slowing the progression of coronary disease remains an untested hypothesis.

\section{Genetic factors}

Recent observations on the relation between $\mathrm{ACE}$ gene polymorphism and the risk of myocardial infarction lend weight to the hypothesis that the renin-angiotensin system may be active in the pathogenesis of coronary artery disease. Although ACE activities are fairly stable within individual people, they show considerable variation between people. ${ }^{25}$ About $50 \%$ of this variability is determined genetically. ${ }^{26}$ Thus the gene which codes for $\mathrm{ACE}^{27}$ is associated with an insertion (I)-deletion (D) polymorphism in intron $16 .{ }^{28}$ People with the DD genotype (one in four of the population) have plasma ACE activities that are on average twice those of people with the II genotype, the ID genotype being associated with intermediate values. Cambien et al compared patients after myocardial infarction with controls and found that the DD genotype was significantly more frequent in patients with myocardial infarction. ${ }^{29}$ Indeed, in those with no other risk factors for myocardial infarction (smoking, hypertension, hyperlipidaemia) the DD genotype increased the risk by a factor of $3 \cdot 6$. They concluded that the DD ACE gene variant, which codes for high activities of ACE, is a potent new risk factor for myocardial infarction. They also postulated that the most likely mechanism by which this ACE gene variant influences the risk of myocardial infarction is by increasing the concentration of angiotensin II locally within the coronary arterial wall.

More recently, these same investigators have reported that in the original study population the DD genotype was associated with excess deaths from ischaemic heart disease in parents, strengthening the hypothesis that genetically determined ACE activity may have a role in the pathogenesis of coronary artery disease. ${ }^{30}$ In response to these new findings, a substudy of QUIET will genetically type all the patients to determine whether the DD variant is indeed a risk factor for ischaemic events and whether administration of the ACE inhibitor quinapril shows differential protective effects in subgroups with and without this variant. If differential effects are identified then it may be possible in future to characterise genetically those patients at special risk of progressive atherosclerosis who would benefit from ACE inhibition.

\section{Conclusion}

A body of experimental, clinical, and genetic evidence implicates the tissue renin-angiotensin system in the pathogenesis of coronary artery disease and myocardial infarction. Whether treatment with ACE inhibitors can modify the progression of coronary artery disease is an exciting hypothesis that is currently being tested in the QUIET study, whose results will be available in 1996.

1 Ganten D, Schelling P, Vecsei P, Ganten U. Iso-renins of extrarenal origin. The tissue angiotensinogenase systems. Am $¥$ Med 1976;60:760-72

2 Oliver JA, Sciacca RR. Local generation of angiotensin II as a mechanism of regulation of peripheral vascular tone in the rat. $\mathcal{\exists}$ Clin Invest $1984 ; 74: 1247-51$.

3 Campbell DJ. The site of angiotensin production. $f$ Hypertens 1985;3:199-207.

4 Dzau VI. Short- and long-term determinants of cardiovascular function and therapy: contributions of vascular function and therapy: contributions of circulating and tissue renin-angiotensin sy
Cardiovasc Pharmacol 1989;14(suppl 4):S1-5.

5 Johnston CI, Mendelsohn FAO, Cubela RB, Jackson B, Kohzuki M, Fabris B. Inhibition of angiotensin converting enzyme (ACE) in plasma and tissues: studies ex vivo after administration of ACE inhibitors. F Hypertens 1988;6(suppl 3):S17-22.

6 Johnston CI, Fabris B, Yamada H, et al. Comparative studies of tissue inhibition by angiotensin converting enzyme inhibitors. 7 Hypertens 1989;7 (suppl 5):S1 1-6.

7 Cleland JGF, Krikler D. Modification of atherosclerosis by agents that do not lower cholesterol. Br Heart $f$ 1993;69(suppl):S54-62.

8 Harrison DG, Armstrong ML, Freiman PC, Heistad DD. Restoration of endothelium-dependent relaxation by dietary treatment of atherosclerosis. F Clin Invest 1987; 80:1808-11.

9 Becker RH, Wiemer G, Linz W. Preservation of endothelial function by ramipril in rabbits on a long-term atherogenic diet. f Cardiovasc Pharmacol 1991;18(suppl 2): S110-5.

10 Schelling P, Fischer H, Ganten D. Angiotensin and cell 
growth: a link to cardiovascular hypertrophy? $f$ Hyperten 991;9:3-16.

11 Powell JS, Clozel J-P, Muller RKM, et al. Inhibitors of angiotensin-converting enzyme prevent myointimal proliferation after vascular injury. Science 1989;245:186-8.

12 Johnston CI, Jandeleit K, Mooser V, et al. Angiotensinconverting enzyme and its inhibition in the heart and blood vessels. I Cardiovasc Pharmacol 1992;20(suppl B):S6-11.

13 Texter M, Lees RS, Pitt B, Dinsmore RE, Uprichard ACG The quinapril ischemic event trial (QUIET) design and The quinapril ischemic event trial (QUIET) design an methods: evaluation of chronic ACE inhibitor therap after coronary artery interventic

14 Multicenter European Research Trial With Cilazapril After Angioplasty to Prevent Transluminal Coronary ObstrucAngioplasty to Prevent Transluminal Coronary Obstruction and Restenosis (MERCATOR) Study Group. Does the new angiotensin converting enzyme inhibitor cilazapril prevent restenosis after percutaneous translumin

15 Burnier M, Mooser V, Nussberger J, Waeber B, Brunner HR. Correlation between plasma concentration of cilazapril and haemodynamic and hormonal effects in healthy man. Br f Clin Pharmacol 1989;27:189-97S.

16 Powell JS, Muller RKM, rouge M, Kuhn H, Hefti $F$, Baumgartner HR. The proliferative response to vascula injury is suppressed by angiotensin-converting enzyme inhibition. F Cardiovasc Pharmacol 1990;16(suppl 4): S42-9.

17 Multicentre European Research Trial With Cilazapril After Angioplasty to Prevent Transluminal Coronary Obstruction and Restenosis (MERCATOR) Study Group. Presented at XVth congress of the European Cardiac Society, September 1991, Amsterdam.

18 CONSENSUS Trial Study Group. Effects of enalapril on mortality in severe congestive heart failure: results of the cooperative north Scandinavian enalapril survival study cooperative north Scandinavian enalapril survival study

19 SOLVD Investigators. Effect of enalapril on survival in patients with reduced left ventricular ejection fractions and congestive heart failure. $N$ Engl f Med 1991; and congestive

20 SOLVD Investigators. Effect of enalapril on mortality and the development of heart failure in asymptomatic patients with reduced left ventricular ejection fractions. $N$ Engl f Med 1992;327:685-91.

21 Pfeffer JM, Pfeffer MA, Braunwald E. Influence of chronic captopril therapy on the infarcted left ventricle of the rat. Circ Res 1985;57:84-95.

22 Pfeffer JM, Pfeffer MA, Steinberg C, Finn P. Survival after an experimental myocardial infarction: beneficial effects of long-term therapy with captopril. Circulation 1985; 72:406-12.

23 Pfeffer MA, Lamas GA, Vaughan DE, Parisi AF, Braunwald E. Effect of captopril on progressive ventricular dilatation after anterior myocardial infarction. N Engl ₹ Med 1988;319:80-6.

24 Pfeffer MA, Braunwald E, Moye LA, et al. Effect of captopril on mortality and morbidity in patients with left ventricular dysfunction after myocardial infarction: results of the survival and ventricular enlargement trial. N Engl f Med 1992;327:669-77.

25 Alhenc-Gelas F, Richard J, Courbon D, et al. Distribution of plasma angiotensin I-converting enzyme in healthy men: relationship to environmental and hormonal parameters. F Lab Clin Med 1991;117:33-9.

26 Cambien F, Alhenc-Gelas F, Herbeth B, et al. Familial resemblance of plasma angiotensin I-converting enzyme level: the Nancy study. Am $f$ Hum Genet 1988; 43:774-80.

27 Soubrier F, Alhenc-gelas F, Hubert C, et al. Two putative active centers in human angiotensin I-converting enzyme revealed by molecular cloning. Proc Natl Acad Sci USA 1988;85:9386-90.

28 Tiret L, Rigat B, Visvikis S, et al. Evidence from combined segregation and linkage analysis that a variant of the angiotensin I-converting enzyme (ACE) gene controls plasma ACE levels. Am F Hum Genet 1992;51:197-205.

29 Cambien F, Poirier O, Lecerf L, et al. Deletion polymorphism in the gene for angiotensin-converting polymorphism in the gene for angiotensin-converting
enzyme is a potent risk factor for myocardial infarction. enzyme is a potent risk

30 Tiret L, Kee F, Poirier O, et al. Deletion polymorphism in angiotensin-converting enzyme gene associated with parental history of myocardial infarction. Lancet 1993; 341:991-2. 